\title{
Os passos da propagação da fé: 0 lugar da experiência em escritos jesuíticos sobre a América quinhentista*
}

\section{Guilherme Amaral Luz}

Os lugares destacados da experiência para a legitimação de juízos políticos sobre a colonização da América (incluindo a conversão de seus habitantes) e a autópsia são identificáveis em escritos jesuíticos tanto da América espanhola quanto da portuguesa, na segunda metade do século XVI. As viagens, a observação das novidades da "quarta parte" do orbe, enfim, as notícias inventariadas no compasso do trabalho missionário na América põem em evidência um repertório ecfrásico ${ }^{1}$ do qual depende a invenção jesuítica do Novo Mundo. Participando de um conjunto de textos que introduzem a América no cenário cosmográfico dos quinhentos, as histórias do novo continente auctorizadas pela Companhia de Jesus necessitam se mostrar verossímeis ao seu público por meio de recursos discursivos estratégicos capazes de convencer o público ao qual se destinavam, incluindo a autópsia. ${ }^{2}$ Para além disso, no entanto, assumir que os objetivos dessas histórias resumiam-se a apresentar um retrato verossímil da quarta parte do mundo seria o mesmo que abstrair os caracteres axiológicos do domínio retórico próprio da escrita jesuítica. Assim, é fundamental considerar, nos diversos registros de gênero da Companhia de Jesus na América, as funções das informações autopsiais para a geração dos efeitos adequados à missão da ordem no novo continente.

\footnotetext{
* Este texto corresponde a uma versão ampliada de outro que foi apresentado nas IX Jornadas Internacionais sobre Missões Jesuíticas (São Paulo, 8-11/10/ 2002), na sessão: "Experiência e evangelização: o papel das circunstâncias no estabelecimento de planos missionários nas Américas (sécs. XVI-XVIII)”. Agradeço, aqui, as colaboraçōes dos demais integrantes da mesa: Beatriz Domingues, Rafael Ruiz e Márcia Eliane Alves Souza e Mello. Pelas sugestôes, agradeço a Leandro Karnal.
} 
Por exemplo, podemos afirmar que o potencial retórico das descrições das novidades das novas terras não tardou a ser incorporado nas disposiçôes inacianas sobre a correspondência jesuítica, conforme demonstra Alcir Pécora. ${ }^{3}$ A função, no caso, a ser desempenhada é, segundo as determinações das Constituiçôes da Companhia de Jesus, tripla: informar, reunir todos os membros dispersos pelo orbe em um só e, por fim, promover a experiência mística ou devocional dos membros da Companhia de Jesus. Em 1554, escrevendo a um missionário na Índia, padre Gaspar Berze, através de seu secretário, padre Polanco, Inácio de Loyola, como Geral da Companhia, ordena que se atenda aos desejos de "pessoas principais" da cidade de Roma que anseiam por ler, nas cartas de edificação vindas das terras exóticas, "algo sobre a cosmografia das regiôes onde andam os nossos; como, por exemplo, quão longos são os dias de verão e de inverno, quando começa o verão, se as sombras vão à esquerda ou à direita. Finalmente, se há outras coisas que pareçam extraordinárias, dê-se aviso, como de animais e plantas desconhecidas ou ao menos não na grandeza encontrada etc.". ${ }^{4}$ A incorporação de informações cosmográficas na narratio das cartas jesuíticas torna-se um instrumento de promoção dos objetivos da escrita epistolar jesuítica, gerando disposição favorável nos homens de corte em relação à missão jesuítica pelo mundo e à edificação de seus espíritos.

Exemplar semelhante de "literatura informativa" jesuítica destinada a gerar ânimos favoráveis à ação missionária são aqueles textos que Charlotte Castelneau-L'Estoile denominou pelo feliz termo de "narrativa de consolação". Aqui, "a consolação corresponde ao estado de manifestação de alegria (épanouissement)", ao assistir à efetivação da "vontade de Deus". Castelnau-L'Estoile entende que, "em um contexto de dificuldades missionárias, Fernão Cardim escolheu a via da 'consolação', totalmente em harmonia com a realidade difícil da missão no Brasil", sobre a qual ela identifica a tópica jesuítica da "vinha estéril". ${ }^{5}$ Nesse sentido, o texto atribuído a Cardim conhecido como Narrativa epistolar de uma viagem e missão jesuitica (1584), ao trazer informaçôes, obtidas na experiência das viagens e visitaçôes, sobre do Novo Mundo e as missōes jesuíticas em seu contexto, articula a autópsia da dura realidade missionária entre os índios do Brasil no interior de um gênero capaz de produzir efeitos favoráveis à continuidade da própria missão. 
Ainda de acordo com a autora, o texto de Cardim está articulado a um repertório mais amplo de escritos heterogêneos que dão corpo ao saber jesuítico sobre a conversão do índio da América portuguesa nos tempos de Visitação. Tais manuscritos estão agrupados no livro Cousas do Brasil, que se encontra na Biblioteca Municipal de Évora. São treze textos ao todo, abarcando cartas de Nóbrega, seu Diálogo sobre a conversão dos gentios, o debate de Caxa e Nóbrega sobre se um pai pode vender seu filho, textos anônimos informativos das missões e das Capitanias do Brasil, além de Do princípio e origem dos indios do Brasil e de seus costumes, adoração e ceremónias e Enformación de la provincia del Brasil para nuestro padre, ambos datados de 1584 e também atribuídos ao padre Cardim. Textos desta natureza - escritos, muitas vezes, por meros coadjutores temporais e que circulavam sob o anonimato — forneciam informações úteis como "matéria-prima” para composição de obras de síntese de padres autorizados da Companhia, mais capazes de produzir um discurso edificante e que servisse como informação aos superiores para o recrutamento de missionários para terras além-mar. ${ }^{6}$

José de Acosta, por sua vez, defende, em seu De procuranda Indorum Salute (1588), que os novos assuntos do Novo Mundo requerem juízos para os quais não basta o bom domínio das Escrituras e da tradição, mas necessitam também do conhecimento das particularidades da terra, o que só se adquire pela experiência. No entanto, isso não significa que a Teologia seja desnecessária para a compreensão dos novos assuntos; pelo contrário, Acosta utiliza o argumento da necessidade da experiência para justificar sua tese de que é preciso haver teólogos eminentes ${ }^{7}$ na América mais do que em qualquer outra parte. Não é, portanto, o homem comum o encarregado de interpretar a novidade reconhecida no "fazer", mas o sábio, mediante a experiência do novo. Esses teólogos deveriam ser os Reitores e Provinciais da Companhia de Jesus na América, aos quais os missionários de conhecimento mediano da doutrina deveriam sempre recorrer. ${ }^{8}$ Aqui, sugere-se uma perfeita harmonia, expressa hierarquicamente, entre experiência e formação teológica para a realização da finalidade máxima da Companhia de Jesus na América: ajudar o próximo (o índio americano) a conhecer o amor de Deus e alcançar a salvação da alma. ${ }^{9}$ 
De procuranda Indorum Salute é, em si, um exemplar de conselho político prudente com base teológica e na observação experiente. Conforme apresenta Luciano Pereña, ${ }^{10}$ nesse tratado, Acosta procurava diagnosticar os problemas do Peru (e das possessões castelhanas na América de forma mais abrangente), buscando as soluçôes mais prudentes e racionais (entendendo racionalidade como juízos em analogia com a provável vontade de Deus). Dentre seus objetivos está acabar com a polêmica acerca da legitimidade da permanência espanhola na América, o que se refere às especulaçōes teológico-políticas da neo-escolástica, desde Vitória, sobre os direitos do Império espanhol Habsburgo sobre a América e seus habitantes. Feita a opção favorável a tal permanência, caberia lançar a base sobre a qual se consertariam os abusos em relação aos novos súditos do Império, lançando instruçóes novas para o povoamento e para a pacificação da terra. Prescrever-se-iam, a partir daí, novas orientações para a conversão e "recristianização" dos índios, articulando as responsabilidades do poder temporal às necessidades espirituais da terra e indicando normas de comportamento, formação, prática e opinião a serem seguidas pelos missionários da Companhia de Jesus. Ao plano de estabelecer um tratado sobre os caminhos espirituais e temporais da conversão, como é De Procuranda Indorum Salute, Acosta aliou a escrita de sua História Natural e Moral das Índias (1590), na qual, à luz de sua suposta experiência ${ }^{11}$ no México, no Peru e no Caribe, fornece uma leitura autorizada do caráter providencial da ocasião de entrada da Religião nas Índias através dos espanhóis.

Já na carta em que Acosta entrega sua História ao proveito da Infanta Dona Isabel da Áustria, percebe-se a sua intenção de fornecer ensinamentos morais retirados da interpretação teologicamente correta da observação da novidade e apresentados na sua leitura aprazível. Sua prosa visa, ao mesmo tempo, ensinar (lectio) e deleitar (delectio). ${ }^{12}$ Os ensinamentos políticos, que se apresentam como conselhos de prudência para a boa consciência do governante, necessitam de uma prosa construída de maneira a produzir deleite, o que Acosta promete oferecer através de um exemplar de escrita histórica. A História, no interior da formação teológica completa do jesuíta, compõe uma das Faculdades Inferiores definidas pelas Constituiçôes da Companhia de Jesus: as Letras de Humanidade. Ao lado dela, pressupóe-se a Retórica e a Poesia e seu objetivo, no caso, é fornecer um 
meio útil, considerando o decoro das ocasiões, para a realização do fim da Companhia. ${ }^{13}$ A História deve ser pensada, no caso jesuítico, como um instrumento retórico de propaganda, o que, na tradição do gênero, é possibilitado pela figura do exemplum. Nesse sentido, é útil lembrar com Hartog, que a História, compreendida no campo da Retórica, "não significa (...) que dispense a exigência de verdade; pelo contrário, ela se afirma com lux veritatis". ${ }^{14} \mathrm{O}$ mais importante, no entanto, é que essas verdades formem uma "coletânea de exempla", podendo ser úteis como "mestre da vida”. A historia magistra uitae, tópica ciceroniana hegemônica no terreno da "historiografia" moderna até o século XIX, ${ }^{15}$ compõe a principal motivação ética das narrativas de viagem autoproclamadas como autopsiais no século XVI, como ocorre em Acosta.

$\mathrm{Na}$ perspectiva da formação do membro da Companhia de Jesus, as artes ou ciências naturais, por sua vez, são tomadas como faculdades que "dispõem o engenho dos discípulos para a Teologia e servem para o conhecimento e uso dela, além de, por si só, ajudarem nos fins mesmos" ${ }^{16} \mathrm{da}$ Companhia de Jesus, como já explicitado. Entre elas, encontram-se a Física e a Metafísica, a Filosofia Natural e a Filosofia Moral, entendidas segundo a doutrina de Aristóteles, sob as restrições pelos Mestres e Reitores das Universidades da Companhia de Jesus, visando o que é mais conveniente “à glória de Deus nosso Senhor". ${ }^{17}$ Assim, em Acosta, quando falamos em História Natural, supomos a descrição edificante da dinâmica dos vários entes do mundo, subordinada ao fim (previsto teleologicamente) que eles tendem a realizar. Já História Moral refere-se aos movimentos arbitrários do homem que, igualmente, devem levar ao fim previsto pelo Criador ou, como o missionário diz em relação ao índio, à sua "vocação do Santo Evangelho" ${ }^{18} \mathrm{O}$ conhecimento das "coisas naturais", devidamente orientado na perspectiva teológica a lhe fornecer sentido, é, portanto, indissociável dos efeitos de deleite a provocarem no leitor devoto. Aliando o conhecimento natural e moral a uma retórica historiográfica dos exempla, temos uma construção teológica para a qual a autópsia é imprescindível como lugar de enunciação. Ao mesmo tempo, ao aliar a experiência nas novas terras com uma seleção moralizada de modelos antigos de descrição do orbe, temse uma narrativa capaz de pôr em evidência uma imagem verossímil do mundo nos padróes do conhecimento cosmográfico quinhentista. A teo- 
logia afirma-se, assim, à luz da verdade e a verdade é iluminada teologicamente.

A matéria da primeira parte da História, disposta segundo os princípios teológicos adequados à produção dos efeitos retóricos desejados, seria a particularidade da natureza das Índias no que está reservado aos seus habitantes quanto à recepção da Palavra e possibilidade de participação na Graça. Nela, cabe identificar as razões prováveis, dentro de uma "História Providencial", para o seu desconhecimento quase completo entre os Antigos e para os sentidos das recentes descobertas dos espanhóis. Nesse caminho, a invenção de Vespúcio, qual seja, a da Zona Tórrida não como lugar hostil à vida, mas, pelo contrário, atrativa a ela, converte-se no principal argumento favorável à tese de que é da vontade de Deus atrair curiosidade e cobiça dos cristãos na direção de povos que, por tanto tempo, ficaram afastados da "luz do Evangelho". Como um evento de tal grandeza não poderia existir sem estar, de alguma maneira, previsto nas profecias, Acosta associa as Índias Ocidentais ao que, nas Escrituras, aparece como Tarsis e dirá ser lícito tomar as recentes descobertas como previstas nas profecias de Abdias. Acosta, além disso, justifica haver povos sem o conhecimento do Evangelho dizendo que, enquanto não chegar o dia do juízo, ainda haverá muito a ser descoberto e revelado aos cristãos como caminho para a obtenção da Glória. ${ }^{19}$

Provada a inclinação natural da descoberta da América e sua exploração pelos espanhóis, Acosta esclarece os intuitos mais devotos de sua História, que se confunde com aquilo que ele próprio considera ser o intuito de Deus ao provocá-la, ou seja, a colaboração dos cristãos para a salvação dos índios, sua vocação histórica natural. ${ }^{20}$ Assim, ele introduz seus livros a respeito dos costumes dos habitantes das Índias, lembrando o caráter exemplar que a narrativa deve ter como ensinamento ao governo cristão prudente, insinuado na carta à Infanta Isabel. Os livros seguintes trazem como matéria os costumes dos habitantes das Índias, seus vícios, suas inclinações, suas formas de uso da razão, suas crenças; enfim, tudo o que pudesse ter algum "valor de uso" para a tarefa evangelizadora. No primeiro livro dessa parte, Acosta trata das "superstições", "idolatrias" e outras formas de "falsa religião" que os índios pudessem ter. Seu objetivo, no caso, é triplo. Em primeiro lugar, é útil conhecer as práticas vis dos 
índios antes de sua cristianização para saber se os que já se converteram dissimulam a Religião. Ao lado disso, tal inventário serve para ampliar o conhecimento das artimanhas do demônio para corromper a humanidade. Em terceiro lugar, uma vez narrado o sucesso da conversão indígena e a derrota do demônio no plano da extirpação da idolatria, dos sacrifícios e das superstiçôes, mover aqueles que vêem os frutos da conversão a dar Graças ao Criador. ${ }^{21} \mathrm{~A}$ descrição dos habitantes das novas terras, realizada na coleta autopsial de "informaçôes brutas" deveria servir a três objetivos: objetivo pastoral, demonologia e consolaçãoledificação. Tais orientações de fim teológico prescreveriam o caminho do olhar na composição ecfrásica do próximo.

Acosta, com suas "informaçôes", argumenta contra os princípios da "servidão natural”, defendidos por Sepúlveda (via Aristóteles), e contra a alegação corriqueira que os corrobora de que os "maus costumes" dos índios devem-se ao fato de serem "amentes" ou "irracionais". ${ }^{22} \mathrm{O}$ "verdadeiro" motivo da "ignorância” da Religião não é atribuído ao índio, mas ao demônio, que aproveita da vulnerabilidade do índio (que vive apartado da Boa Nova) para convencê-los da legitimidade de seu culto, que nada mais seria do que a perversão do verdadeiro culto de Deus. Os argumentos contra a "irracionalidade" dos habitantes do Novo Mundo são acentuados no livro seguinte, que trata das suas formas particulares de uso da razão. ${ }^{23} \mathrm{Tal}$ inventário serve ao missionário para concluir que os índios possuem capacidade natural de serem ensinados e de bom uso da razão. Mais do que isso, ele afirma que um objetivo central em se ter notícia das leis, dos costumes e da "polícia” dos índios é “(...) ajudá-los e regi-los por elas mesmas, pois, naquilo que não contradizem a lei de Cristo e de sua Santa Igreja, devem ser governados conforme seus foros". ${ }^{24}$

Sustenta-se aqui a legitimidade do dominium dos índios e, portanto, de sua organização política particular, prevendo a ação missionária apenas como adequação dessa organização à Doutrina e às "leis naturais", o que é possível não só mediante o ensino pacífico e pela razão, mas, sobretudo, pelo uso prudente das ocasiões históricas dispostas providencialmente. É dando seqüência a este argumento que Acosta arrolará, no livro seguinte, os sentidos previamente dispostos pelo Criador para a História dos mexicanos. A noção ética básica dessa escrita histórica é derivada por Acosta de 
um trecho do Eclesiastes, que ele cita no capítulo primeiro do último livro de sua História. Diz-se nas Escrituras:

O que foi será; o que aconteceu, acontecerá: nada há de novo debaixo do sol.

Mesmo que se afirme: 'Olha: isto é novo', eis que já aconteceu em outros tempos, muito antes de nós.

Não ficou memória dos antepassados, nem dos vindouros ficará lembrança para os que vierem depois. ${ }^{25}$

Nessa passagem, sustenta-se a formulação de Acosta de que

qualquer história, sendo verdadeira e bem escrita, traz não pouco proveito ao leitor. Não há gente tão bárbara que não tenha nada a elogiar, nem há tão política e humana que não se tenha o que emendar. ${ }^{26}$

Aqui, a Revelação é considerada incompleta e precária na temporalidade mundana, sujeita ao esquecimento e a ser relembrada, mas prevista desde o início pelo intelecto divino onisciente. Isso leva o missionário a conceber que "a verdade" encontra-se distribuída desigualmente pelo mundo e, tanto os mais civilizados quanto os mais bárbaros, têm o que aprender sobre "ela" uns com os outros. Os feitos dos bárbaros, assim, também são dignos de memória, pois, tais como os feitos dos civilizados, são formas imperfeitas de perceber o caminho previsto pelo Criador e Redentor para aos fins da história da humanidade. A escuta recíproca das suas histórias particulares pelos homens que se encontram divididos pelas diversas regiōes do mundo é uma estratégia, que fica clara neste livro, de conversão por argumentos racionais e pacíficos. Acosta pressupõe que, dando crédito aos feitos dos bárbaros (mexicanos), esses poderiam ficar mais inclinados a dar atenção aos cristãos em suas próprias experiências. Desse modo, crê que a notícia das histórias leve a um encontro racional de ambas as partes com "a verdade" da História. Do lado cristão, propiciaria um olhar desenganado sobre o índio: homens virtualmente capazes de uso da razão e da prudência. Do lado indígena, propiciaria a percepção de que os cristãos trazem-lhe a luz do Evangelho para a sua salvação.

O que tanto a descrição bruta e o inventário da idolatria e superstiçôes indígenas, de suas leis e formas de se governarem quanto a escuta das 
histórias dos índios fornecem a Acosta é um conjunto de argumentos que se apresentam como verdades aparentemente autônomas em relação à voz do narrador, comprobatórias de teses teológicas que se afirmam ao longo da narração/descrição. Desse modo, a História é eficaz como produtora da anulação de uma voz que, através do engenho, poderia engendrar, nas matérias apresentadas, um modelo de ação ou de virtudes. Antes disso, o narrador apresenta-se tão-somente como o relator de uma experiência que, por si só, traria à vista a verdade intrínseca do conteúdo observado. Nesse processo, a História ainda traria para dentro de si outras histórias ouvidas, produzindo, em um "espectro" de diálogo, uma anulação das diferenças, entendidas, tal como apresentadas, como formas variantes de uma natureza única que convergem para um ponto de fuga: a Revelação. Em outros termos, nesse pseudodiálogo, o acordo afirma-se previamente como a natureza humana universal que se assume de antemão como destinada ao conhecimento do amor de Deus e da salvação.

Caber-nos-ia, então, perguntar, com Michel de Certeau, se a escrita histórica jesuítica não se enquadraria no que poderíamos chamar de uma "etno-grafia". Certeau, em relação aos deslocamentos da escrita entre os séculos XVI e XVIII no que se refere ao "homem selvagem", trata-os como constituição de um saber de tipo heterológico, que, através de uma economia escriturística, criaria um espaço para o "outro" no discurso, mediante o qual o referencial identitário de origem deveria encontrar os caminhos para a sua reposição. ${ }^{27} \mathrm{~A}$ similaridade entre o que pode ser observado no caso jesuítico e no caso do huguenote Jean de Léry (principal exemplar do qual Certeau extrai suas conclusões a respeito da "etno-grafia") é bastante evidente. No entanto, é preciso reconhecer que a operação escritural de Léry parte de uma situação particular de contato com os índios, ${ }^{28}$ funciona de acordo com os pressupostos teológicos da impossibilidade da conversão do Tupinambá ${ }^{29}$ e visa objetivos políticos distintos daqueles previstos na escrita jesuítica. ${ }^{30}$ Em Léry, a escrita caminha para o reconhecimento da similaridade entre realidades humanas inconfundíveis (a comunidade dos eleitos e os “outros"). Nos escritos jesuíticos, identifica-se a convergência das diferenças na direção de uma humanidade única, universal e inalienável. Enquanto em Léry pode-se falar de uma "escrita do outro", nos textos jesuíticos seria mais adequado pensar em uma "escrita do próximo". 
Mas o último e mais importante desenvolvimento da concepção cristã de História em Acosta é que, percebendo a dos mexicanos, ele diz:

(...) se poderá entender a disposição que o altíssimo Deus quis escolher para enviar a estas nações a luz do Evangelho de seu unigênito Filho, Jesus Cristo, Nosso Senhor, ao qual suplico que enderece este nosso pequeno trabalho, de sorte que traga a glória de sua divina grandeza e alguma utilidade a estas gentes a quem comunico sua santa lei evangélica. ${ }^{31}$

Aqui, a leitura correta da História é aquela que se faz "com a ajuda do Criador". Isto é: narrar a história de maneira inspirada é compreendê-la no interior da História providencial, que, ainda assim, dá-se a ler de maneira imperfeita. No último capítulo do livro e de todo o tratado, são, finalmente, elencados os elementos históricos que evidenciam "a disposição que a Divina Providência ordenou nas Índias para a entrada da religião cristã nelas". São eles, basicamente, três. Primeiro, a grande riqueza de ouro e prata sob domínio dos povos tanto do México quanto do Peru, ${ }^{32}$ o que constituiria um incentivo para a sua sujeição ao Império cristão. Segundo, o ápice do poder de Montezuma, adorado e temido como homem e como Deus em um amplo território comparável a Roma no tempo da chegada de Cristo. Por conta da centralização do seu poder, várias nações e gentes estavam conquistadas e reduzidas a uma única língua, facilitando a comunicação dos cristãos com os habitantes das suas variadas partes. ${ }^{33}$ Por último, havendo grandes divisóes entre os índios, a conquista dos primeiros espanhóis com a ajuda das nações rivais seria facilitada. ${ }^{34}$

No arranjo particular de Acosta da História dos mexicanos, levando teleologicamente à realização da vontade de Deus de trazer aos povos americanos o Evangelho, percebe-se, com valor de evidência, a defesa dos principais métodos de conversão que apresenta o seu De procuranda indorum salute. Em primeiro lugar, devemos mencionar o aproveitamento dos territórios já ocupados por espanhóis, nos quais os habitantes já estariam sujeitos à jurisdição dos príncipes cristãos. Isso se justifica por um princípio segundo o qual, ainda que muitas conquistas sejam movidas por interesses materiais e de forma injusta, a cobiça pelas riquezas descobertas na América é, como vimos, um elemento providencial que busca aproximar os evangelizadores dos povos do Novo Mundo. Sua finalidade, portanto, acaba 
sendo justa. Em segundo lugar, Acosta repele qualquer idéia de escravidão natural dos índios, mas justifica um relacionamento provisoriamente duro e, até mesmo violento, para se conter o barbarismo nativo manifesto, sobretudo, na sua "falsa religião". Tudo isso concorre para a defesa de se aproveitar a sujeição violenta dos nativos do Novo Mundo ao poder do Império apesar dos denunciáveis excessos de violência do processo, como aparecem em Vitória ou Las Casas. Afinal, a conquista dos índios já estava providencialmente preparada.

Se Nóbrega não se ocupou a escrever qualquer texto de gênero "histórico" ou "cosmográfico" sobre a América que estivesse baseado em sua experiência in locu, isso não significa que, diferentemente de Acosta, estivesse menos preocupado em autorizar as políticas missionárias através da experiência ou, ainda, que elas seguissem, de modo geral, as mesmas perspectivas já apontadas em relação a Acosta. ${ }^{35}$ No caso da América portuguesa, os escritos jesuíticos de caráter mais histórico foram escassos, tiveram pouca circulação até o século XIX e nenhum deles é atribuído a Nóbrega. ${ }^{36}$ No lado português do novo continente, as informações cosmográficas e históricas provenientes dos jesuítas encontram-se, sobretudo, no gênero epistolar, seguindo os preceitos de Inácio de Loyola nas Constituiçôes e em suas próprias correspondências, como já adiantamos. ${ }^{37}$ Das cartas de Nóbrega é paradigmática - quanto ao caráter de escrita histórica com base na autópsia e na leitura teológica correta dos fatos — a que remete em 1559 a Tomé de Sousa, relatando as primeiras ações do novo governador, Mem de Sá. Nela, o terceiro governador aparece como um justiceiro capaz de reatar os caminhos da colonização da terra (previstos quando da ida dos primeiros jesuítas e do próprio destinatário, primeiro governador geral, à América portuguesa) aos fins devotos previstos nela: a conversão do gentio. Claramente inspirada no livro bíblico dos Juízes, a carta estabelece princípios de bom governo para a empresa missionária e ultramarina portuguesa na América através dos exempla históricos do "heróico" governador, que aparece como aquele que chega na terra para restaurar a ordem que se via ameaçada pelas discórdias anteriores entre o governador Duarte da Costa e o bispo Sardinha e pelos maus exemplos dos cristãos que viviam na terra. ${ }^{38}$

Nos elogios de Nóbrega às ações do terceiro governador, destacam-se aquelas que se assemelham ao modelo defendido por Acosta de conversão 
do gentio com base na sua sujeição política, conquistada mediante o uso prudente da "guerra justa", a saber: o "ajuntamento" de índios em aldeamentos onde seriam ensinados na Doutrina por padres da Companhia de Jesus, a proibição da antropofagia e a punição "justa" dos delitos cometidos seja por índios ou por moradores. Tais ações serviriam como matéria, posteriormente, na confecção do épico atribuído a Anchieta que fica conhecido como De gestis Mendi de Saa, no qual os feitos heróicos do governador indicam o caminho da entrada (ou sujeição) do bárbaro na esfera da vida política, anunciando o retorno de uma primavera dos tempos. Aqui, a experiência dos fatos da história recente da colonização, lidos em analogia com fontes da tradição religiosa católica, presta-se ao anúncio divino da sua vontade providencial, cuja mensagem circunstancial gera a convicção da justiça no uso do medo para obter o consentimento indígena da sua redução à fé propagada pelos padres da Companhia. Desse modo, a experiência dos fatos à luz dos sucessos dos feitos do governador, tais como narrados, colaboram na justificativa de sentidos a serem levados a cabo pela a empresa missionária dos inacianos.

O plano jesuítico de geração do consentimento indígena pelo medo é tratado por José Eisenberg em, sobretudo, dois escritos de Nóbrega anteriores à sua carta de 1559 a Tomé de Sousa: Diálogo da conversão dos gentios (1556-1557) e Carta do P. Manuel da Nóbrega ao P. Miguel de Torres (1558). ${ }^{39}$ Para Eisenberg, esses escritos são marcos da mudança da convicção jesuítica inicial da facilidade de conversão por argumentos para a concepção, mediada pela experiência, de que o medo da guerra é o fundamento do poder político legítimo, que adviria do consentimento dos súditos da perda da "liberdade" propiciada pelo "estado natural". ${ }^{40}$ Assim, para o autor, os escritos de Nóbrega preparariam as mudanças nas teorias políticas sobre a origem da sociedade civil, pensadas pelos jesuítas do final do século XVI - sobretudo, Juan de Mariana (De Rege et Regibus Institutione - 1599) e, em menor grau, Luís de Molina (De Iustitia et Iure — 1592-1593) antecipando a formulação das teorias contratualistas seiscentistas de Hugo Grotius e Thomas Hobbes.

Embora, de fato, no final do século XVI e do século XVII, as teorias políticas que trazem noções de consentimento pelo medo ganhariam prestígio, seria anacrônico pensar que, nas décadas de 1550 e 1560, Nóbrega poderia lançar mão delas sem maiores dificuldades para justificar sua polí- 
tica missionária. No Diálogo sobre a conversão dos gentios (1556-57), Nóbrega não chega a deixar explícito que a geração do consentimento do índio deveria advir do medo, mas que o missionário não deve abster-se de praticar a caridade com o próximo, desistindo da tarefa aparentemente árdua de criar as condições através das quais o índio pudesse se converter à Religião. A tarefa de converter, diria Nóbrega através de Matheus Nogueira, compete somente a Deus e aos missionários cabe colaborar com a providência, tornado o índio mais disposto para a conversão, pois essa é a obrigação de amor e caridade da qual depende, nem tanto a salvação do índio, mas a deles próprios. A chave para a conversão não está, assim, colocada, em primeiro plano, na geração do medo do índio, mas na ação obstinada dos missionários no concerto dos "maus hábitos". Ela está na confiança de que os frutos da conversão virão por obra da providência uma vez estando retos os caminhos da empresa missionária, que não se afasta do plano político prudente e, portanto, de arbítrio humano ajuizado.

O que, no âmbito deste artigo, no entanto, mais nos interessa é perceber que, para tratar de assunto tão controverso e mover os seus comandados à ação missionária, Nóbrega, como Provincial da Companhia de Jesus, optou por um gênero bastante adequado, o diálogo. Nele, escolheu, ainda, dois irmãos (um língua, Gonçalo Alves, e um ferreiro, Matheus Nogueira) como interlocutores, cujos lugares são o da experiência e não o da especulação pura. É a partir desses lugares que, ao longo da conversação, uma teologia da conversão do gentio pode aflorar. Nela, a coerção e o medo não são os princípios a partir dos quais o índio deveria ser reduzido à sociedade política sob o controle da união Estado-Igreja, mas, uma vez estando justamente inserido no corpo político do Estado, deveria estar sujeito às leis e puniçôes que lhe pudessem consertar os costumes adquiridos em sua "rude criação". Tal projeto está na base da política dos aldeamentos, onde se constitui um espaço intermediário entre a rudeza e a "cidade dos homens” análoga à de Deus, capaz de promover a entrada do índio na sociedade política.

Discorrendo sobre o Diálogo de Nóbrega, Alcir Pécora identifica, no emprego jesuítico do gênero, pelo menos quatro elementos oriundos da tradição humanista de matriz platônica que lhe configuram. Em primeiro lugar, ele constitui-se discursivamente como dramatização da vitória argu- 
mentativa sobre o oponente, de modo que sua disposição desdobra etapas de um combate intelectual, cuja eficiência persuasiva está na crítica ou formação de um juízo voluntário e racional por parte do auditório (leitor/ ouvinte). Em segundo lugar, ele registra-se por um estilo "informal" ou familiar, como que imitando alguém que fala de improviso. O sermo, nesse sentido, presta-se a constituição de um discurso refinado, porém não demasiadamente especializado, através do qual é produzido um ambiente propício (um locus amoenus) para o convívio intelectual e para o "prazer honesto da companhia”. Além disso, ele dispõe de uma cena dramática mínima, na qual há a presença de personagens de posiçôes intelectuais distintas, formando uma situação que exige uma prática racional tal como pretendido em uma república (no sentido renascentista do termo) ${ }^{41}$ ou em uma "cidade ideal". Por último, ele seleciona personagens representativos de tradições ou escolas distintas, que mais se confrontam do que cooperam. Na confrontação, as falas particulares são reordenadas na direção de um acordo ou de um "verossímil universal". ${ }^{42}$

Sendo assim, Pécora conclui que o gênero dialógico ${ }^{43}$ em sua aplicação jesuítica em questão é "adequado para a defesa de uma posição, entre outras possíveis, formuladas a respeito de um tema potencialmente polêmico, dado numa situação prática, cuja resolução satisfatória implica a consideração progressiva de aspectos universais, desconhecidos em graus diversos pelas suas personagens". Pécora entende que o momento da escrita do diálogo, 1556-57, exige esta defesa, no qual ele identifica a tomada de posição de Nóbrega favorável à sujeição do gentio como método missionário. ${ }^{44}$ Em sua dissertação de Mestrado sobre o Diálogo sobre a conversão do gentio, Maria Fátima de Melo Toledo oferece-nos ainda outros elementos da conjuntura teológico-política do momento que permitem avançar nesta questão. O principal parece ser a discordância entre os próprios padres jesuítas no Brasil (polarizado em Nóbrega e em seu sucessor no provincialato do Brasil, Luís da Grã) e entre a cúpula romana e portuguesa da Companhia de Jesus (sobretudo entre o Geral Diego Laynes e o Provincial de Portugal Miguel Torres) sobre os caminhos a se adotarem como metodologia missionária, notoriamente no que se refere aos limites da introdução de elementos culturais indígenas nas cerimônias religiosas cristãs e sobre o sacerdócio indígena. ${ }^{45} \mathrm{O}$ Diálogo, a nosso ver, possibilita- 
ria a manutenção da coesão do corpo da ordem, gerando um ambiente propício ao convívio intelectual de posições conflitantes, permitindo o seu confronto na busca por um acordo racional, expandindo o campo das opiniōes aceitáveis. ${ }^{46} \mathrm{O}$ Diálogo será, assim, um instrumento capaz de considerar os assuntos polêmicos, como o consentimento pelo medo, no interior de uma racionalidade tipicamente neotomista.

Assim como na História, onde a autópsia figura como locus fundante de um discurso teológico aplicado ao caso, no Diálogo de Nóbrega, a experiência missionária como lugar a partir do qual os interlocutores disputam e colaboram no sentido de gerar um acordo sobre os caminhos da conversão do gentio da América portuguesa é um recurso central. Através dela, o constructo teológico apresenta-se indissociável dos casos particulares que se mostram à luz das evidências experienciadas no cotidiano da missão pelos seus agentes mais rústicos: os coadjutores temporais. Mais uma vez, encontramo-nos diante de um processo de autorização do discurso teológico pela voz daquele cujo saber se dá mais pela prática do que pelo estudo dos livros. O sentido das falas rústicas experientes, no entanto, produz efeitos mais ou menos eficazes quando se demonstram mais ou menos atinadas a uma lógica análoga à “vontade de Deus”. Portanto, mantém-se a hierarquia entre experiência e formação intelectual subordinada aos fins teologicamente justos da empresa jesuítica.

Por sua vez, em De gestis Mendi de Saa (1563), Anchieta fornece a chave através da qual a entrada do índio no corpo político torna-se acessível: eles serem bárbaros não é razão para lhes mover guerra justa, mas, por serem bárbaros e cruéis, vêm, recorrentemente, cometendo alguma ofensa injusta aos cristãos, justificando uma guerra defensiva cuja vitória estaria sempre do lado do justo (no caso, Mem de Sá e seus homens) que deve aproveitar (e, no caso, o Governador aproveita) a ocasião da pacificação para torná-los sujeitos às leis positivas e mais dispostos, com o tempo, à conversão. Mais uma vez, a providência parece agir a favor da conquista do território americano pelos cristãos, mostrando-lhes os caminhos para prosseguir na tarefa caritativa de evangelização, na sua experiência. A astúcia do governante cristão prudente está em perceber, nas circunstâncias propícias que experiencia, a ocasião para o seu uso adequado na direção do cumprimento da missão. Indissociados dos seus princípios teológicos (de suas 
causas primeiras), os fatos engendram conteúdos morais experenciáveis no fazer caridoso e evidenciáveis na escrita engenhosa.

Sendo a experiência necessária para a compreensão dos caminhos providencialmente traçados para as políticas missionárias, os diversos casos de consciência e as decisões políticas devem passar pelo exame prudente dos fatos, ou seja, da história recente da conversão. É isso que está na base, por exemplo, das Respostas do P. Manuel da Nóbrega ao P. Quirício Caxa $(1567)^{47}$ quanto à legitimidade ou não de um pai vender seu filho ou si mesmo, seja em caso de grande ou extrema necessidade. Para Nóbrega, a resposta não estará colocada apenas no corpo de textos de autoridades, mas, sobretudo, no exame das práticas que deram origem ao próprio impasse levado à Mesa de Consciência e Ordens: o cativeiro indígena tomado como injusto e praticado através de artimanhas dos moradores que enganam os índios ou lhes expóem a uma situação de tal necessidade que não lhes restaria outra escolha além de se venderem como escravos. Assim, Caxa, recém-chegado à terra, ainda que muito versado em teologia e em casuísmo, é respondido pela voz da experiência de um ex-provincial, canonista e de formação completa, que, estando na terra já havia dezoito anos, prefere especular a providência in contingentia facti. Melhor dizendo, Nóbrega, tal como um Bartolomé de Las Casas, "usa o 'fato' para interpretar a 'lei' e a 'lei' para situar o 'fato", ${ }^{48}$ pois, como em Domingo de Soto, "os fatos do caso provêm a base para a leitura autorizada do texto". ${ }^{49}$ Experiência e cânon engendram-se em um círculo hermenêutico, cuja separação seria a quebra dos sentidos e das formas de legitimação (ou autorização) do discurso.

Em suma, a dinâmica entre experiência e saberes teologicamente orientados mostra-se, nos escritos jesuíticos sobre a América e seus habitantes, como um modus operandi retórico, gerando efeitos adequados à missão, assumida, desde o princípio, como a razão de ser da própria experiência no Novo Mundo. Nos casos avaliados, o lugar da experiência articula-se hierarquicamente às verdades reveladas nas circunstâncias ocasionais, permitindo a visualização do novo no interior da História cristã. A invenção do Novo Mundo vem, assim, acompanhada de uma reinvenção da tradição teológica no interior de práticas cristãs em um solo estranho e árido à semeadura do Evangelho, que se rende à ação astuta e prudente, mediada pela experiência. 


\section{Notas}

${ }^{1}$ Sobre as narrativas quinhentistas sobre o índio da América portuguesa, João Adolfo Hansen oferece-nos seus dois princípios estruturantes que operam em conjunto: a ecfrase e a hermenêutica teológico-política. O primeiro encarrega-se de recolher, pelo olho, todo o visível, compondo ut pictura poiesis cenas e quadros justapostos que dão, ao entendimento do leitor, a visibilidade do "novo". O segundo submete as imagens criadas ecfrasicamente "à memória dos saberes autorizados do signo". Assim, a dispersão produzida no acúmulo de detalhes descritivos da escrita, via ecfrase, seria reunificada pela "interpretação teológico-política da enunciação”. Ver: HANSEN, João Adolfo. Sem F, sem L, sem R: cronistas, jesuítas e índio no século XVI. In: Cadernos Cedes n. ${ }^{\circ}$ 30, 1993. pp.45-46.

${ }^{2}$ Sobre as novas estratégias do saber cosmográfico, a partir do advento da quarta parte do mundo, sugerimos: LESTRINGANT, Frank. L'Atelier du cosmographe ou l'image du monde à la Renaissance. Paris: Albin Michel, 1991. Segundo o autor, a descoberta do Novo Mundo passa a exigir uma flexibilização dos modelos antigos no caminho da incorporação das novas terras, promovendo o crescimento do papel da autopsia na direção do que denomina uma "inadaptação fecunda dos modelos".

${ }^{3}$ Ver: PÉCORA, Alcir. A arte das cartas jesuíticas do Brasil. In: Máquina de gêneros, São Paulo: Edusp, 2001. pp.17-68.

${ }^{4}$ LOYOLA, Ignácio de. Al P. Gaspar Berze. Roma, 24 febrero 1554. In: Obras de San Ignácio de Loyola, Madrid: Biblioteca de Autores Cristianos, 1991. p. 985. Tradução livre.

${ }^{5}$ CASTELNAU-L'ESTOILE, Charlotte de. Les ouvriers d'une vigne stérile: les jésuites et la conversion de Indiens au Brésil, 1580-1620, Lisboa: Fundação Caluste Gulbenkian, 2000. pp. 354-355.

${ }^{6}$ Idem p. 377.

${ }^{7}$ Trata-se de missionários com formação teológica completa (absoluta theologie facultate instructos).

${ }^{8}$ ACOSTA, José de. De procuranda indorum salute - Corpus hispaniorum de pace vol. XXIV, Madrid: Consejo Superior de Investigaciones Cientificas, 1987. pp. 90-95.

${ }^{9}$ A finalidade e a missão da Companhia de Jesus são expostas recorrentemente em vários trechos das Constituições. Delas não escapam os objetivos da formação teológica (Escolástica, Escritura e Teologia Positiva) dos padres da Companhia e de seus estudos das "Faculdades Inferiores”: Letras de Humanidades (Gramática, Retórica, Poesia e História), Lógica, Física, Metafísica, Matemáticas, Filosofia Natural, Filosofia Moral e Línguas grega, latina, hebréia, caldéia, arábica e indiana. Ver: LOYOLA, Ignácio de. Constituciones de la Compañia de Jesus. In: Obras de San Ignácio de Loyola... pp. 558-559.

${ }^{10}$ ACOSTA, José de. De procuranda indorum salute - Corpus hispaniorum de pace vol. XXIII, Madrid: Consejo Superior de Investigaciones Cientificas, 1984. p.14. 
${ }^{11}$ Apesar de Acosta colocar-se como observador autopsial das informaçôes que provê, ele não atuava como missionário junto aos índios e não é inverossímil pensar que muitas de suas informaçôes (ou mesmo a sua maioria) tenham sido retiradas de fontes escritas anteriormente, como as crônicas e histórias da conquista do México (ver, por exemplo, as relaçôes entre Acosta e o Frei Diego Durán estabelecidas por Ángel Garibay em sua nota introdutória ao texto do dominicano. Ver: DURÁN, Frey Diego. Historia de las Indias de Nueva España e islas de la tierra firme — tomo I, México: Editorial Porrúa. Edição preparada por Ángel Ma. Garibay K. pp. XXXV-XXXVII) e, sobretudo, do encomiendero Pollo de Ondegardo, cujo texto, Notables daños de no guardar a los indios sus fueros (1571), forma a base das informações de Acosta sobre o Peru, e Pe. Juan de Trovar, missionário jesuíta que lhe proveu as informações sobre o México (Ver: MARZAL, Manuel M. Historia de la Antropologia vol. I - la Antropologia indigenista: Mexico y Peru, Lima: Pontificia Universidad Catolica del Peru / Fondo Editorial,1986. p. 97). Assim, a experiência não pode ser entendida como o ponto inicial para o recolhimento de informações, mas como lugar, no discurso, de autorização das informaçōes como fidedignas. Além disso, diferentemente do seu contemporâneo franciscano Bernardino de Sahagún, cuja aspiração nominalista produziu o mais completo "compendium" sobre os índios mexicanos (seus costumes e sua "falsa religiāo"), Historia de las cosas de la Nueva España (c. 1582), Acosta preocupa-se menos em inventariar os particulares do que em desvendar a razão de ser das matérias do Novo Mundo.

${ }^{12}$ Diz Acosta: “(...) pois que o conhecimento e especulação das coisas naturais, principalmente quando notáveis e raras, causa natural gosto e deleite em entretenimentos delicados e, igualmente, a notícia de costumes e feitos estrangeiros apraz com sua novidade, tenho para mim que V. A. poderá se servir de um honesto e útil entretenimento ao dar ocasião de considerar as obras que o Altíssimo fabricou na máquina deste mundo, especialmente naquelas partes que chamamos Índias, que, por ser novas terras, dão mais o que considerar e, por serem novos vassalos os que o Sumo Deus deu à Coroa da Espanha, não é sem sentido ter conhecimento" (ACOSTA, José de. Historia naturaly moral de las Indias - en que se tratan de las cosas notables del cielo / elementos / metales / plantas y animales dellas / y los ritos / y ceremonias / leyes y gobierno de los indios, México: Fondo de Cultura Económica,1985. p. 09).

${ }^{13}$ LOYOLA, Ignácio de. Constituciones de la Compañia de Jesus. In: Obras de San Ignácio de Loyola... p. 559.

${ }^{14}$ HARTOG, François. A arte da narrativa histórica. In: BOUTIER, Jean \& JULIA, Dominique (orgs.). Passados recompostos - campos e canteiros da História, Rio de Janeiro: Editora da UFRJ/ Editora da FGV, 1998. p. 197.

${ }^{15}$ Sobre o assunto, sugerimos o texto: KOSELLECK, Reinhart. Historia magistra vitae: the dissolution of the topos into the perspective of a modernized historical process. In: Future past — on the semantics of historical time, Cambridge-MA: MIT Press. pp. 21-38. ${ }^{16}$ LOYOLA, Ignácio de. Constituciones de la Compañia de Jesus. In: Obras de San Ignácio de Loyola... pp. 559. 
${ }^{17}$ Idem pp. 562-563.

${ }^{18}$ ACOSTA, José de. Historia natural y moral de las Índias... p. 14.

${ }^{19}$ Diz Acosta: “(...) o Salvador (...) nos afirma que se predicará o Evangelho em todo o mundo e que, então, verão o fim, certamente declara que enquanto dura o mundo há ainda gentes a quem Cristo não tenha sido anunciado. Portanto, devemos concordar que faltou aos antigos grande parte a conhecer e que a nós, hoje em dia, está encoberta uma parte não pequena do mundo" (idem. p. 45).

${ }^{20}$ Diz Acosta: “(...) o intento desta história não é somente dar notícia do que se passa nas Índias, sem se endereçar esta notícia ao fruto que se pode retirar do conhecimento de tais coisas, que é ajudar aquelas gentes para a sua salvação e glorificar o Criador e Redentor, que os tirou das trevas obscuríssimas de sua infidelidade e lhes comunicou a admirável luz de seu Evangelho" (idem. p. 215).

${ }^{21}$ Idem. p. 278-9.

${ }^{22}$ HANKE, Lewis. Estudios sobre Fray Bartolome de las Casas y sobre la lucha por la justicia en la conquista española de America, Caracas: Universidad Central de Venezuela, 1968. pp. 301-339.

${ }^{23}$ Ver também: VITÓRIA, Francisco de. Obras de Francisco de Vitoria: relecciones teologicas, Madrid: Biblioteca de Autores Cristianos,1960. p. 664.

${ }^{24}$ ACOSTA, José de. Historia natural y moral de las Indias... p. 281.

${ }^{25}$ Eclesiastes 1, 9-11.

${ }^{26}$ ACOSTA, José de. Historia natural y moral de las Indias... p. 319.

${ }^{27}$ Ver: GIARD, Luce. Epilogue: Michel de Certeau's heterology and the New World. In: Representations, 33, Winter. pp. 212-221, 1991. \& CERTEAU, Michel de. A escrita da história, Rio de Janeiro: Forense-Universitária, 1982. pp. 219-226.

${ }^{28}$ Andréa Daher, a partir de Frank Lestringant, avalia a situação de contato entre franceses e Tupinambá através de dois conceitos-chave: o fenômeno do "endotismo" e a formação de alianças através dos truchements. Diz a autora: "a penetração dos franceses na inextrincável tessitura social indígena era condição para as alianças com os tupinambá, visando, num primeiro momento, garantir a eficácia das relaçôes comerciais. Mas ela acabou, após vários anos de contato, produzindo uma verdadeira mestiçagem através dos truchements. Das narrativas em língua francesa que descrevem a 'acomodação' dos truchements no meio tupinambá e a 'mestiçagem' franco-tupi, uma das primeiras é a Histoire d'um Voyage, de Jean de Léry, que não se furta a uma descrição radical dos fatos, expondo o risco do triunfo da selvageria sobre os espíritos civilizados." (DAHER, Andréa. "Do selvagem convertível”. In: Topoi. Revista de História. Rio de Janeiro: 7Letras, set. 2002, pp. 71-107). No caso jesuítico, o "endotismo" seria indesejável, estando a familiarização com a tessitura cultural do índio sempre subordinada à finalidade de instrumentalização de elementos culturais descontextualizados a favor da redução das diferenças.

${ }^{29}$ Uma vez excluindo os Tupinambá do plano da salvação, Léry poderia tratá-los como ocupando um lugar radicalmente distinto do seu no plano da humanidade, estando liberados a viverem segundo os seus próprios preceitos. Essa é uma das teses de Lestringant 
em: LESTRINGANT, Frank. Le huguenot et le sauvage, Paris: Aux Amateurs de Livres, 1990.

${ }^{30}$ A própria impossibilidade da conversão do índio repele a motivação política mais central da escrita jesuítica: a missão. Nesse sentido, a própria colonização espanhola/portuguesa da América seria ilegítima aos olhos do huguenote.

${ }^{31}$ ACOSTA, José de. Historia natural y moral de las Indias... p.320.

${ }^{32}$ Idem p. 374. É interessante, ainda, relacionar esta consideração de Acosta com as relações entre obtenção de ouro e favor divino em outros "cronistas" da América. Pagden (PAGDEN, Anthony. "Ius et factum: text and experience in the writings of Bartolomé de Las Casas"... pp. 85-86), por exemplo, demonstra como, Oviedo, em sua História general y natural de las Indias, entende a obtenção de ouro como favorecimento divino à alma purificada, casta e obediente à lei natural.

${ }^{33}$ ACOSTA, José de. Historia natural y moral de las Indias... p.374.

${ }^{34}$ Idem. p. 375 . Os três elementos podem ser visualizados na segunda e na terceira carta de relação de Hernán Cortés a Carlos V (CORTÉS, Hernán. Cartas de relación, Mexico: Editorial Porrúa, 1994. pp. 31-172). Sobre as rivalidades entre "nações", na Nova Espanha, ela se polarizaria, principalmente, entre Tlascala e México e, no Peru, entre Atahualpa e Huascar.

${ }^{35}$ Ver: PÉCORA, Alcir. A arte das cartas jesuíticas do Brasil... p. 52-60.

${ }^{36}$ Os textos a que nos reportamos são: Breve informação do Brasil (1585) e Informação do casamento dos indios (c. 1570), atribuídos a Anchieta (ANCHIETA, José de. Textos históricos, São Paulo: Loyola,1989. pp. 35-82) e aos dois manuscritos atribuídos a Fernão Cardim (Do clima e terra do Brasil e Do princípio e origem dos indios do Brasil - c. 1584) que se encontram em Évora e que foram publicados, por Capistrano de Abreu e Rodolfo Garcia, junto com Narrativa epistolar de uma viagem e missão jesuítica, como Tratados da terra e gente do Brasil. Entre esses escritos de Cardim e Anchieta há, como observaram Capistrano de Abreu e Rodolfo Garcia, muitas coincidências e semelhanças, ambas podendo ter bebido na mesma fonte ou mesmo Anchieta ter imitado seu colega de ordem. Ver na introdução ao Tratado de Cardim elaborada por Rodolfo Garcia (CARDIM, Fernão. Tratados da terra e gente do Brasil, São Paulo: Cia Editora Nacional, 1936. p. 20). Embora não tendo sido escrito por um missionário, mas por um leigo oficial da administração do Governo Mem de Sá, podemos encontrar inúmeras semelhanças, inclusive éticas, entre as "histórias" jesuíticas e os tratado e história de Pero de Magalhães Gandavo (GANDAVO, Pero de Magalhães. Tratado da terra do Brasil; História da província de Santa Cruz, Belo Horizonte: Itatiaia, 1980).

${ }^{37}$ No caso do Brasil, em 1560, seis anos após à já comentada carta do padre Polanco ao padre Gaspar Berze, obedecendo a uma ordem de Nóbrega, Anchieta escreve uma carta ao Geral da Companhia bem na trilha do modelo que estabelece Inácio de Loyola em relação às informações cosmográficas. Nela, fica evidente que a continuidade das descobertas de novidades, motivo que atrai o leitor esperado pela carta, é colocada em função do aumento da experiência missionária na terra, ou seja, da continuidade da "conversão 
do país”. O lugar da experiência, deste modo, é colocado como mecanismo legitimador da empresa missionária, assim como somente a empresa missionária justificaria a permanência e a experiência da Companhia de Jesus - e dos próprios portugueses — na terra (Ver: ANCHIETA, José de. Cartas de Anchieta, correspondência ativa e passiva, São Paulo: Loyola, 1984. pp. 123-152). Essa carta de Anchieta pode ser tomada como paradigmática do uso da informação cosmográfica adquirida pela experiência, no caso, do "rústico" (Anchieta, no momento, era tão-somente um irmão), para os objetivos mais espirituais da Companhia de Jesus nas terras de além-mar.

${ }^{38}$ Ver: NÓBREGA, Manuel da. Cartas do Brasil (1549-1560), Belo Horizonte — São Paulo: Itatiaia — Edusp, 1988. pp. 191-219.

${ }^{39}$ Os dois textos encontram-se reproduzidos em: EISENBERG, José. As missóes jesuiticas e o pensamento político moderno, Belo Horizonte: Editora da UFMG, 2000. pp. 222-246.

${ }^{40}$ Além do estudo de Eisenberg, sugerimos o artigo: CHAMBOULEYRON, Rafael. A evangelização do Novo Mundo: o plano do padre Manuel da Nóbrega. In: Revista de História, São Paulo, USP, no. 134, pp. 37-47, 1996.

${ }^{41}$ Inspirada na República Romana e particularmente forte na primeira metade do século $\mathrm{XV}$, a república pode ser sumariamente entendida como uma forma de governo em que o ponto central é a participação dos "excelentes" nas decisões políticas e não a centralização delas exclusivamente na figura de um monarca. Para uma visão mais profunda do tema no início da Idade Moderna, sugerimos: GUENÉE, Bernard. O Ocidente nos séculos XIV e XV (os Estados), São Paulo: Pioneira / Edusp, 1981.

42 PÉCORA, Alcir. "A conversão pela política”. In: Máquina de gêneros... pp. 97-98.

${ }^{43}$ Para um panorama a respeito da diálogo no humanismo português, sugerimos: OSÓRIO, Jorge A. "O diálogo no humanismo português". In: O humanismo português (1500-1600): Primeiro Simpósio Nacional (21-25 de Outubro de 1985), Lisboa: Publicações do II Centenário da Academia de Ciências de Lisboa, 1988. pp. 383-412.

${ }^{44}$ PÉCORA, Alcir. "A conversão pela política”... p. 99.

45 TOLEDO, Maria Fátima de Melo. O sonho da quimera: uma análise do Diálogo sobre a conversão do gentio do padre Manuel da Nóbrega, Dissertação de Mestrado, São Paulo: Universidade de São Paulo, 2000. Ver o capítulo III: “A razão a serviço da fé”, pp. 73-95.

${ }^{46}$ Chaïm Perelman afirma que, no diálogo, a controvérsia de opiniōes "tem como efeito estender ou modificar o campo do razoável”. Neste sentido, novas teses, uma vez vinculadas às precedentes, podem ser integradas ao conjunto das opiniōes aceitas (Ver: PERELMAN, Chaïm. A linguagem: pragmática e dialógica. In: Retóricas, São Paulo: Martins Fontes, 1999. pp. 52-53).

${ }^{47}$ Os textos de Caxa e Nóbrega, que restam como os documentos conhecidos do embate, encontram-se em: NÓBREGA, Manuel da. Cartas do Brasil e mais escritos - Edição facsimilar comemorativa dos 500 anos da descoberta do Brasil. Belo Horizonte: Itatiaia, 2000. pp. 397-430. A resposta de Nóbrega é reproduzida também em: EISENBERG, José. As missóes jesuíticas e o pensamento político moderno... pp. 247-264. 
48 PAGDEN, Anthony. "Ius et factum: text and experience in the writings of Bartolomé de Las Casas". In: GREENBLATT, Stephen (Ed.). New World encounters, Berkeley: University of California Press, 1993. p. 96.

${ }^{49}$ Idem p. 91.

\section{Resumo}

Neste artigo, avalia-se o papel da experiência como um lugar que autoriza o discurso jesuitico sobre as Américas no século XVI. O deslocamento missionário dos inacianos para a América, ao mesmo tempo em que se apresenta como meio legitimador de relatos fidedignos sobre a nova terra e seus habitantes, mostra-se, no horizonte dos textos que produz, como princípio teológico que confere seus sentidos e orientaçóes finalistas. São tomados, como casos exemplares disso, escritos de José Acosta e Manuel da Nóbrega, buscando perceber neles, nem tanto as circunstâncias especificas de cada jesuita, mas o núcleo comum típico de um modus operandi da Companhia de Jesus no Novo Mundo.

\section{Abstract}

The aim of this article is to evaluate the role of experience as a mechanism that authorised Jesuit discourses on Americas in the Sixteenth Century. The missionary displacement of the Inacians to America can be faced both as a mean to legitimate accurate discourses about the new land and its inhabitants and the theological principle that provide meaning and finalist orientation to their texts. Pieces of writing by José Acosta and Manuel da Nóbrega are taken here rather as examples of this typical modus operandi of the Company of Jesus in the New World than different circumstances to be compared. 